\title{
Mixing models and stable isotopes as tools for research on feeding aquatic organisms
}

\section{Cyntia Rafaela Ferreira de Moraes $^{1 *}$ (iD) Gustavo Gonzaga Henry-Silva ${ }^{2}$}

\begin{abstract}
'Programa de Pós-graduação em Ciência Animal, Universidade Federal Rural do Semi-Árido (UFERSA), Av. Francisco Mota, 572, 59625-900, Mossoró, RN, Brasil. E-mail: cyntia_orion@yahoo.com.br. "Corresponding author.

${ }^{2}$ Laboratório de Limnologia e Qualidade de Água (LIMNOAQUA), Universidade Federal Rural do Semi-Árido (UFERSA), Av. Francisco Mota, 572, 59625-900, Mossoró, RN, Brasil.
\end{abstract}

\begin{abstract}
Implementation of mixture models in isotopic analysis has been increasing due to the need to analyze sources and understand their variations in relation to consumers, which requires an accurate determination of their discriminant rate and fractioning. In this context, we presented the main concepts related to the application of stable isotopes and mixing models, with the aim to analyze the benefits and problems of these tools in surveys on nutrition of aquatic organisms. The predominant methods identified included application of the models IsoSource, MixSIR, SIBER and SIAR, with the use of C and N isotopes in research with aquatic organisms. Studies in both freshwater and marine environments were evaluated to determine the relative contribution of the main food items and understand trophic relationships between organisms. It can be concluded that the application of mixing models, with the stable isotope technique, is a promising tool for research on feeding aquatic organisms and understanding issues related to trophic ecology of these organisms.
\end{abstract}

Key words: food, nutrition, diets, fish.

Modelos de mistura e isótopos estáveis como ferramentas para pesquisas sobre alimentação de organismos aquáticos

RESUMO: Os modelos de mistura nas análises isotópicas vêm sendo cada vez mais utilizados devido à necessidade de analisar as fontes alimentares e compreender suas variações em relação aos consumidores, o que requer uma adequada determinação de suas taxas discriminantes e fracionamentos. Neste contexto, objetivamos apresentar os principais conceitos relacionados à aplicação de isótopos estáveis e modelos de mistura, visando analisar as vantagens e desvantagens destas ferramentas em pesquisas com nutrição de organsimos aquáticos. Foram identificados de forma predominante a aplicação dos modelos IsoSource, MixSIR, SIBER e SIAR, com a utilização dos isótopos de C e N em pesquisas com organismos aquáticos, tanto em ambientes dulcícolas como em ambientes marinhos para determinar a contribuição relativa dos principais itens alimentares e compreender relações tróficas entre organismos. Pode-se concluir que, a aplicação dos modelos de mistura com a técnica de isótopos estáveis compõe uma ferramenta promissora nas pesquisas sobre alimentação de organismos aquáticos e na compreensão de questões relacionadas à ecologia trófica destes organismos.

Palavras-chave: alimento, nutrição, dietas, peixe.

\section{INTRODUCTION}

Analysis of the eating habits of individuals of a particular species makes possible to understand how food items are consumed, as well as how they are available and distributed in the environment. Furthermore, the quantity and quality of the assimilated food influence the allocation of nutrients to animal tissues and organs (ZUANON, 2003). To understand the contribution of food items in aquatic environments, data obtained from traditional and chemical analyses provides essential information to understand the trophic dynamics of communities and for the conservation of ecosystems (CORRÊA \& SILVA, 2010; PESSOA et al., 2012; 2013a; 2013b; GAMBOA-DELGADO et al., 2013; FRANCO et al., 2014).

In recent decades, there has been increased research using techniques involving stable isotopes (DENIRO \& EPSTEIN, 1977; 1978; 1981; FANTLE et al., 1999; FRY, 2006; 2008; BEZERRA et al., 2015; VIGHI et al., 2016; NACHEV et al., 2017). This analysis is widely used to investigate various 
scientific issues pertaining to organisms and their ecosystems, especially concerning eating habits and availability of nutritional sources in life stages, whether in their natural environment or in captivity (PASQUAUD et al., 2010; GONDWE et al., 2011; 2012; KADYE \& BOOTH, 2012; LETOURNEUR et al., 2013; RAO et al., 2015).

The tissue isotopic concentration of animals provides insight into their dietary history, and some authors propose that fish isotopic ratios are similar to the food they eat most (CAUT et al., 2009; BOECKLEN et al., 2011; FRANCO et al., 2014). Use of the stable isotope technique has some advantages over conventional approaches, such as analysis of gut contents and direct observations, especially because it is possible to determine more precisely the dietary components assimilated and used for animal growth (LI et al., 2013). Given the above, we aimed to present the main concepts related to application of stable isotopes and mixture models, aiming to analyze simultaneously the benefits and problems of these tools, especially in research on nutrition of aquatic organisms.

\section{Concepts and application of stable isotopes}

Isotopes are atoms that have the same numbers of protons, but have different numbers of neutrons (BISI et al., 2012; PHILIPPSEN \& BENEDITO, 2013). Isotopic composition of ratios between elements of any substance is presented in the form of notation $\delta$ (delta), as the isotopic ratios of carbon and nitrogen $\left({ }^{13} \mathrm{C} /{ }^{12} \mathrm{C}\right.$ and $\left.{ }^{15} \mathrm{~N} /{ }^{14} \mathrm{~N}\right)$ for example (BISI et al., 2012). These isotopic ratios are obtained using Equation 1, based on the natural abundance of elements used (LEAL et al., 2008; PHILIPPSEN \& BENEDITO, 2013).

$\delta(\mathrm{X})=\left[\left(\mathrm{R}_{\text {sample }} / \mathrm{R}_{\text {standard }}\right)-1\right]^{*} 1000 \quad$ Equation 1 Where: $\mathrm{X}(\%)$ is the value of isotopic abundance of the chosen element, such as ${ }^{13} \mathrm{C}$ or ${ }^{15} \mathrm{~N}$, and $\mathrm{R}_{\text {sample }}$ is the relationship between the isotopic forms of the element, for example ${ }^{13} \mathrm{C}:{ }^{12} \mathrm{C}$ or ${ }^{14} \mathrm{~N}:{ }^{15} \mathrm{~N}$, and $\mathrm{R}_{\text {standard }}$ is the standard used. For $\delta^{13} \mathrm{C}$, the standard is the Peedee Belemnite (PDB) fossil of the mollusc Belemnitella Americana (DUCATTI et al., 2007). For $\delta^{15} \mathrm{~N}$, the accepted international standard is that of atmospheric air $\left(\mathrm{NO}_{2}\right)$, which is considered a mixture homogeneous isotopes on the earth's surface (DUCATTI et al., 2007).

Signatures of the natural abundance of isotopes can be used to find patterns and mechanisms at the level of a single organism, as well as to trace food webs, understand paleodietary studies and cycling of nutrients throughout the ecosystem, in both terrestrial and aquatic systems (FRY, 2008). However, the use of these techniques depends on fundamental issues, such as information on food sources and prey (FINLAY \& KENDALL, 2007).

Isotopic techniques have provided better understanding on how organisms incorporate the elements they consume and have been use in several lines of research and with different taxonomic groups (PHILIPPSEN \& BENEDITO, 2013). Among telements, the most used stable isotopes are carbon, nitrogen, sulfur, oxygen and hydrogen. They can be analyzed together or separately, depending on the purpose of the study (PEREIRA \& BENEDITO, 2007).

Isotopic ratios of $\delta^{13} \mathrm{C}$ and $\delta^{15} \mathrm{~N}$ are the most frequently used (MARTINELLI et al., 1988; MANETTA \& BENEDITO-CECÍIO, 2003; PEREIRA \& BENEDITO, 2007) especially in trophic ecology studies (PHILIPPSEN \& BENEDITO, 2013). The isotopic ratios of $\mathrm{C}$ and $\mathrm{N}$ of the consumer, for example, present a trophic enrichment compared to the isotopic composition of the diet (BISI et al., 2012). Carbon isotopes function as markers, since they fractionate very little in the food chains, while nitrogen isotopes are used commonly in processes to estimate trophic positions (FRY et al., 1999; VANDER ZANDEN et al., 1999; TIUNOV, 2007; CAUT et al., 2009).

Stable isotopes undergo fractionations that occur during chemical, physical and biological processes, which result in different isotopic signatures for different biological materials (GANNES et al., 1998). This difference occurs when isotopes are fractionated in animal tissues. Due to their metabolic activity, species which feeds on different nutritional items, will present fractions and/or the discriminant rate relative to each type food consumed (DENIRO \& EPSTEIN, 1978; FRY, 2006; MARTINELLI et al., 2009). Thus, contributions of food items are not transmitted directly and simply, but they take a specific time and have a certain complexity, requiring specific knowledge of fractionation or discriminant rate for each food item. This requires a more careful analysis for proper application of isotope data in mixing models.

Some authors refer to the discrimination factor as fractionation, fractionation factor or trophic enrichment (MARTINEZ DEL RIO et al., 2009; PHILIPPSEN \& BENEDITO, 2013). Understanding concepts of fractionation, enrichment and discriminant rate, makes possible to use the mixing models to estimate and determine the relative contribution of food items consumed by aquatic organisms. 
The term "fractionation" is in reality related to kinetic and equilibrium effects, which cause the differences and variations between reagents and products in chemical reactions (MARTINEZ DEL RIO et al., 2009; PHILLIPPSEN \& BENEDITO, 2013). In this sense, these authors suggested the term "discrimination factor" (Equation 2) only be used when the work involves determining the difference in isotopic ratio between a particular consumer tissue and your food item. They also explain that the term "trophic fractionation" (Equation 3), should be used when analyzing the whole body of an individual in relation to their food sources (MARTINEZ DEL RIO et al., 2009; PHILLIPPSEN \& BENEDITO, 2013). This distinction is essential to standardize each terminology and to provide proper application of discriminant rates and/or trophic fractionation in mixing models.

$\Delta=\delta$ animal tissue $-\delta$ food item

Equation 2

$\Delta$ trophic $=\delta$ whole body $-\delta$ food item Equation 3

According to PHILIPPSEN \& BENEDITO

(2013), there is a noticeable increase in research on the variability of the discriminant factor, resulting from the popularization of the technique of stable isotopes and their relevance to ecology, combined with the development and improvement of technologies. These authors also pointed out that the recent perception, by part of researchers, that the use of a constant value was not ideal for all taxonomic groups, showing the need to understand the sources of variation for the discriminant factor, since these sources of variation compromise the performance of this technique as a research tool for animal feed.

\section{Stable isotopes in research with aquatic organisms}

In research using stable isotopes as indicators of the nutrition of a particular animal species, one aspect considered is how much a tissue type integrates and isotopically reflects the animal's diet. Thus, muscles are widely used in research due to ease in using and integrating the isotopic dietary signal (MARTINELLI et al., 2009). PHILIPPSEN \& BENEDITO (2013) carried out a bibliographic analysis and verified that among the tissues analyzed with fish; the muscle was the most used $(40.2 \%)$, followed by liver $(14.6 \%)$ and the whole body $(9.8 \%)$. Muscle is accepted as the most suitable tissue for stable isotope analysis, due to reduced amount of lipids, inorganic carbonates and less variation compared to other organs (liver, heart and fin) (PINNEGAR \& POLUNIN 1999; SUZUKI et al., 2005; PHILLIPPSEN \& BENEDITO, 2013).

These other organs denote interest for use according to the type of research. The use of structures such as fins and scales become attractive because it is not necessary to sacrifice the animals used. Already the use of the whole body occurs when the species has a reduced body size that makes difficult to collect samples and specific tissues (SUZUKI et al., 2005; GERMAN \& MILES, 2010; PHILIPPSEN \& BENEDITO, 2013). However, PHILIPPSEN \& BENEDITO (2013) showed that the use of the whole body is not the ideal sample, as it results in values with high isotopic variations (FOCKEN \& BECKER, 1998). In this context, it is essential to have knowledge about species, environment and factors that influence the performance of this technique, because if the analytical problems and methodological approaches are ignored it may compromise the reliability of results.

FRANCO et al., (2014) explain that, despite his contribution in trophic studies, stable isotope analysis also has its limitations. These authors mention as potential problems isotopic fractionation $(\Delta \delta)$ and the turnover rate, which is defined as the time required for the signature of a consumer to reflect the isotopic composition of prey and relies on biotic and abiotic factors (MANETTA \& BENEDITO-CECÍIO, 2003; BOECKLEN et al., 2011).

It is known that the isotopic composition of food sources also varies seasonally, which may create the so-called problem of isotopic memory, related to turnover rates (MARTINELLI et al., 2009). Isotopic turnover it is a continuous renewal of chemical elements and their isotopes that make up the body tissue or the organism as a whole, which may occur through tissue renewal or by growth during tissue formation (DUCATTI, 2007). This change in the isotopic composition of the tissue depends on the assimilation of constituents ingested (CALDARA et al., 2010).

Another important factor considered by FRANCO et al. (2014) was the fractionation $(\Delta)$, which can also be denominated as discriminant factor or rate. Among the factors mentioned in the literature that cause variability in isotopic signatures referring to fractionation factor and/or discriminant rate, we can mention: type of diet (PHILIPPSEN \& BENEDITO, 2013; HEALY et al., 2017); temperature, balance between diet and consumer, age of individuals (PHILIPPSEN \& BENEDITO, 2013); metabolic activity (MARTINELLI et al., 2009); consumer tissue type (CAUT et al., 2009; HEALY et al., 2017); taxonomic group of the consumer and isotopic value of the diet (CAUT et al., 2009); nutritional stress, diet quality, body size, excretory mechanisms, feeding rate (HOBSON \& WELCH, 1995; PONSARD \& AVERBUCH, 1999; OVERMAN \& PARRISH, 
2001; PINNEGAR et al. 2001; VANDERKLIFT \& PONSARD, 2003; MILL et al., 2007); the lipid content and the amino acid composition (WOLF et al., 2009); phylogeny, isotopic signature of sources and the error associated with measures within a species, with the importance of each source of element dependent variation (Nitrogen, Carbon) and taxonomic class (Aves, Mammalia) (HEALY et al., 2017). CAUT et al. (2009) still show in their review research that other factors (diet quality, type of excretion and trophic level) not considered in their research can influence the variations. Thus, sources of variation should be considered for determining discriminant rate and/ or trophic fractionation more reliably, mainly in the application of these data in mixing models.

ZUANON et al. (2007) formulated diets based on grains from the $\mathrm{C}_{3}$ and $\mathrm{C}_{4}$ photosynthetic cycle's plants for analyzing the turnover of muscle carbon in Nile tilapia growth. Fish were fed the experimental diets ad libitum until the muscle $\delta^{13} \mathrm{C}$ approached the carbon isotopic equilibrium, which occurred after 43 days. After the muscle $\delta^{13} \mathrm{C}$ standardization period, fish had their diets changed (the ones fed on the $\mathrm{C}_{3}$ diet, switched to the $\mathrm{C}_{4}$ diet and vice-versa). Fish were fed ad libitum until the carbon isotopic equilibrium of muscle was reached again, after 57 days. Muscle $\delta^{13} \mathrm{C}$ changes of Nile tilapia was verified and were consistent with the $\delta^{13} \mathrm{C}$ of the supplied diets; nevertheless, the carbon isotopic equilibrium was reached only for the $\mathrm{C}_{3}$ diet. These authors sugested that, the tissue metabolic activity can be evaluated by comparison of the carbon half-life values between different tissues of the same species or with the same tissue between different species.

As evidenced in research with juvenile pacu Piaractus mesopotamicus, FIOD et al. (2010) concluded that the isotopic composition of muscle tissue varied according to the food frequency, and fish fed two to three times a day presented a closer composition to the composition of the new food consumed. In the same way, other authors denote the importance of these studies for diverse research on the biology and ecology of different groups and species of aquatic organisms, which explore stable isotopes of various elements, with higher incidence of the $\delta^{13} \mathrm{C}$ and $\delta^{15} \mathrm{~N}$ ratios, and low incidence of isotope ratios of $\delta^{34} \mathrm{~S}, \delta^{18} \mathrm{O}, \delta^{66} \mathrm{Zn}$ and $\delta^{202} \mathrm{Hg}$ in these surveys (Table 1).

Some of this research was carried out with species of freshwater fish, both in their natural habitat and in captivity, especially with grass carp, silver carp (XIA et al., 2013), tambaqui, pacu (ABIMORAD \& CASTELLANI, 2011) and Nile tilapia (GONDWE et al., 2011; 2012; RAO et al., 2015). These studies aimed to evaluate the contributions of natural and artificial foods, in order to try to reduce the supply of feed these fish are given and, consequently, make cultivation more sustainable (GONDWE et al., 2011; 2012; BRITO et al., 2014; ZORZAL-ALMEIDA \& FERNANDES, 2014; MORAES, 2016). MORAES (2016), when using stable isotopes of $\mathrm{C}$ and $\mathrm{N}$ as indicators of the diet of the Nile tilapia (O. niloticus) cultivated in net-cage in a reservoir in the Semi-Arid region of Rio Grande do Norte, concluded that the natural food contributed predominantly in the growth of this species. This type of research fills in the gaps existing on nutritional aspects of cultivated species for assimilation of natural and artificial food, especially for production and cultivation in natural environments.

Other research has been developed with animals in their natural environment, in order to understand the relations and trophic interactions in their habitat (RAO et al., 2015; ENDJAMBI et al., 2016; NAMAN et al., 2016; NACHEV et al., 2017). These stable isotope surveys also allow more precise understanding the biology and ecology of different groups of aquatic organisms. Among these researchs, we can highlight the one developed by NAMAN et al. (2016) that used the technique of stable isotopes and mixing model to establish and understand the complexity of the trophic structure of pelagic fish and jellyfish in estuarine environments.

\section{Mixing models for the analysis of stable isotopes Mixture models have commonly been} used in research involving the use of stable isotopes, both in ecology in the natural environment and in experimental research, with different species of aquatic organisms. Several programs have been developed for the use of mixing models in research, such as: IsoError (PHILLIPS, 2001), IsoConc (PHILLIPS \& KOCH, 2002; KOCH \& PHILLIPS, 2002), IsoSource (PHILLIPS \& GREGG, 2003), IsotopeR (HOPKINS \& FERGUSON, 2012), MixSIR (MOORE \& SEMMENS, 2008), SIAR (PARNELL et al., 2010; 2013), SIBER (JACKSON et al., 2011), IsoWeb (KADOYA et al., 2012), MixSIAR (STOCK \& SEMMENS, 2013), SISUS (ERHARDT, 2014), FRUITS (FERNANDES et al., 2014) and DEsiR (HEALY et al., 2017). In table 2, we present research that used mixing models as a statistical tool to determine the relative contribution of food items in the nutrition of aquatic organisms.

The IsoError and IsoConc programs make possible work with models targeted for two isotopes, with two or three food sources. In their work using the IsoError program, PHILLIPS \& GREGG (2001) 
Mixing models and stable isotopes as tools for research on feeding aquatic organisms.

Table 1 - Use of stable isotopes in research on feeding aquatic organisms.

\begin{tabular}{|c|c|c|c|}
\hline Common name & Scientific name & Isotopes & Authors \\
\hline Tilapia aurea & Oreochromis aureus & $\delta^{13} \mathrm{C}$ & Schroeder (1983) \\
\hline Nile Tilapia & Oreochromis niloticus & $\delta^{13} \mathrm{C} ; \delta^{13} \mathrm{C}$ and $\delta^{15} \mathrm{~N}$ & $\begin{array}{l}\text { Lochmann \& Perschbacher (2000), Zuanon et al. } \\
\text { (2007); Lochmann (2002), Kelly \& Martínez del } \\
\text { Rio (2010), Rao et al. (2015), Moraes (2016) }\end{array}$ \\
\hline Tilapia & O. karongae and O. shiranus & $\delta^{13} \mathrm{C}$ and $\delta^{15} \mathrm{~N}$ & Gondwe et al. (2012) \\
\hline Tilapia & Oreochromis niloticus & $\delta^{13} \mathrm{C}$ and $\delta^{15} \mathrm{~N}$ & Britton et al. (2009) \\
\hline $\begin{array}{l}\text { Catfish } \\
\text { sharptooth } \\
\text { african }\end{array}$ & Clarias gariepinus & $\delta^{13} \mathrm{C} ; \delta^{13} \mathrm{C}$ and $\delta^{15} \mathrm{~N}$ & $\begin{array}{l}\text { Lochmann \& Perschbacher (2000); Lochmann } \\
\text { (2002), Kadye \& Booth (2012) }\end{array}$ \\
\hline Blue catfish & Ictalurus furcatus & $\delta^{13} \mathrm{C}, \delta^{15} \mathrm{~N}$ and $\delta^{34} \mathrm{~S}$ & MacAvoy et al. (2001) \\
\hline Channel catfish & Ictalurus punctatus & $\delta^{13} \mathrm{C}, \delta^{15} \mathrm{~N}$ and $\delta^{34} \mathrm{~S}$ & MacAvoy et al. (2001) \\
\hline Silver carp & Hypophthalmichthys molitrix & $\delta^{13} \mathrm{C}$ and $\delta^{15} \mathrm{~N}$ & Li et al. (2013), Xia et al. (2013) \\
\hline Bighead carp & Aristichthys nobilis & $\delta^{13} \mathrm{C}$ and $\delta^{15} \mathrm{~N}$ & Li et al. (2013) \\
\hline $\mathrm{Pacu}$ & Piaractus mesopotamicus & $\delta^{13} \mathrm{C}$ and $\delta^{15} \mathrm{~N}$ & Fiod et al. (2010) \\
\hline $\begin{array}{l}\text { Japanese } \\
\text { flounders }\end{array}$ & Paralichthys olivaceus & $\delta^{13} \mathrm{C}$ and $\delta^{15} \mathrm{~N}$ & Tominaga et al. (2003) \\
\hline Blue threadfin & Eleutheronema tetradactylum & $\delta^{18} \mathrm{O}$ and $\delta^{13} \mathrm{C}$ & Newman et al. (2011) \\
\hline Whiting & Merlangius merlangus & $\delta^{13} \mathrm{C}$ and $\delta^{15} \mathrm{~N}$ & Chouvelon et al. (2014) \\
\hline European hake & Merluccius merluccius & $\delta^{13} \mathrm{C}$ and $\delta^{15} \mathrm{~N}$ & Chouvelon et al. (2014) \\
\hline $\begin{array}{l}\text { Atlantic horse } \\
\text { mackerel }\end{array}$ & Trachurus trachurus & $\delta^{13} \mathrm{C}$ and $\delta^{15} \mathrm{~N}$ & Chouvelon et al. (2014) \\
\hline Anglerfish & Lophius piscatorius & $\delta^{13} \mathrm{C}$ and $\delta^{15} \mathrm{~N}$ & Chouvelon et al. (2014) \\
\hline Artic Charr & Salvelinus alpinus & $\delta^{13} \mathrm{C}$ and $\delta^{15} \mathrm{~N}$ & Murdoch et al. (2013) \\
\hline $\begin{array}{l}\text { Whitemouth } \\
\text { croakers }\end{array}$ & Micropogonias furnieri & $\delta^{13} \mathrm{C}$ and $\delta^{15} \mathrm{~N}$ & Mont'Alverne et al. (2016) \\
\hline Barbels & Barbus barbus & $\delta^{13} \mathrm{C}$ and $\delta^{15} \mathrm{~N}$ & Nachev et al. (2017) \\
\hline $\begin{array}{l}\text { Brown-marbled } \\
\text { grouper }\end{array}$ & Epinephelus fuscoguttatus & $\delta^{13} \mathrm{C}$ and $\delta^{15} \mathrm{~N}$ & Chen et al. (2012) \\
\hline Sharks & $\begin{array}{l}\text { Bull sharks (Carcharhinus leucas) and Tiger } \\
\text { sharks (Galeocerdo cuvier) }\end{array}$ & $\delta^{13} \mathrm{C}$ and $\delta^{15} \mathrm{~N}$ & Matich et al. (2010) \\
\hline White Sharks & Carcharodon carcharias & $\delta^{13} \mathrm{C}$ and $\delta^{15} \mathrm{~N}$ & Carlisle et al., (2012) \\
\hline Sharks & \multicolumn{2}{|c|}{$\begin{array}{cc}\text { Bonethead (Sphyrna tiburo), Atlantic sharpnose } & \delta^{13} \mathrm{C} \\
\text { (Rhizoprionodon terraenovae), Bull Shark (Carcharhinus } & \text { and } \\
\text { leucas), and White Shark (Carcharodon carcharias) } & \delta^{15} \mathrm{~N}\end{array}$} & Olin et al. (2013) \\
\hline Gastropods & \multicolumn{2}{|c|}{$\begin{array}{cc}\text { Lepetodrilus elevatus, Lepetodrilus pustulosus, Lepetodrilus } & \delta^{13} \mathrm{C} \\
\text { ovalis, Eulepetopsis vitrea, Cyathermia naticoides, Peltospira } & \text { and } \\
\text { delicata, Peltospira operculata and Rhynchopelta concêntrica } & \delta^{15} \mathrm{~N}\end{array}$} & Gaudron et al. (2015) \\
\hline Oyster & Crassostrea gigas & $\delta^{13} \mathrm{C}$ and $\delta^{15} \mathrm{~N}$ & Leal et al. (2008) \\
\hline Bivalve mollusk & Pinna nobilis Linnaeus & $\delta^{13} \mathrm{C}$ and $\delta^{15} \mathrm{~N}$ & Cabanellas-Reboredo et al. (2009) \\
\hline Cladocerans & $\begin{array}{c}\text { Diaphanosoma spinolosum andCeriodaphnia } \\
\text { cornuta }\end{array}$ & $\delta^{13} \mathrm{C}$ and $\delta^{15} \mathrm{~N}$ & Caraballo et al. (2011) \\
\hline Shrimp & Litopenaeus vannamei & $\begin{array}{c}\delta^{13} \mathrm{C} ; \delta^{15} \mathrm{~N} ; \delta^{13} \mathrm{C} \text { and } \\
\delta^{15} \mathrm{~N}\end{array}$ & $\begin{array}{l}\text { Gamboa-Delgado \& Le Vay (2009a); Gamboa- } \\
\text { Delgado \& Le Vay (2009b);Gamboa-Delgado et } \\
\text { al. }(2013 ; 2014)\end{array}$ \\
\hline Crayfish & $\begin{array}{l}\text { Orconectes propinquus and Orconectes } \\
\text { rusticus }\end{array}$ & $\delta^{13} \mathrm{C}$ and $\delta^{15} \mathrm{~N}$ & Taylor \& Soucek (2010) \\
\hline Blue Crab & Callinetes sapidus & $\delta^{13} \mathrm{C}$ and $\delta^{15} \mathrm{~N}$ & Fantle et al. (1999) \\
\hline Common Terns & Sterna hirundo & $\delta^{13} \mathrm{C}$ and $\delta^{15} \mathrm{~N}$ & Bond \& Diamond (2011) \\
\hline $\begin{array}{l}\text { Balearic } \\
\text { Shearwaters }\end{array}$ & Puffinus mauretanicus & $\delta^{13} \mathrm{C}$ and $\delta^{15} \mathrm{~N}$ & Bond \& Diamond (2011) \\
\hline Little penguin & Eudyptula minor & $\delta^{13} \mathrm{C}$ and $\delta^{15} \mathrm{~N}$ & Chiaradia et al. (2014) \\
\hline Green sea turtle & Chelonia mydas & $\delta^{13} \mathrm{C}$ and $\delta^{15} \mathrm{~N}$ & Seminoff et al. (2006); Bezerra et al. (2015) \\
\hline $\begin{array}{l}\text { California sea } \\
\text { otter }\end{array}$ & Enhydra lutris nereis & $\delta^{13} \mathrm{C}$ and $\delta^{15} \mathrm{~N}$ & Newsome et al. (2012) \\
\hline $\begin{array}{l}\text { Arctic marine } \\
\text { mammals }\end{array}$ & $\begin{array}{l}\text { Walruses (Odobenus rosmarus), Bearded seals } \\
\text { (Erignathus barbatus), Ringed seals (Pusa } \\
\text { hispida), and Polar bears (Ursus maritimus), }\end{array}$ & $\delta^{13} \mathrm{C}, \delta^{15} \mathrm{~N}$ and $\delta^{66} \mathrm{Zn}$ & Jaouen et al. (2016) \\
\hline Fin whale & Balaenoptera physalus & $\delta^{13} \mathrm{C}$ and $\delta^{15} \mathrm{~N}$ & Vighi et al. (2016) \\
\hline Biota & $\begin{array}{l}\text { Plant (Potamogeton pectinatus),Mosqui } \\
\text { (Chironomidae), Amphipod (Gammaridea), } \\
\text { (Notonectidae), Snail (Radix sp.), Juvenile a } \\
\text { (Gymnocypris namensis and Gymnocypris wa } \\
\text { shelduck eggs (Tadorna ferruginea), and Cla1 } \\
\text { sp.) }\end{array}$ & $\begin{array}{ll}\text { arvae } & \\
\text { swimmers } & \delta^{13} \mathrm{C}, \\
\text { adult fish } & \delta^{15} \mathrm{~N} \\
\text { lli), Ruddy } & \text { and } \\
\text { Sphaerium } & \delta^{202} \mathrm{Hg}\end{array}$ & $\mathrm{Xu}$ et al. (2016) \\
\hline
\end{tabular}
$s p$.) 
Table 2 - Use of mixing models in research with aquatic organisms.

\begin{tabular}{|c|c|c|c|}
\hline Common name & Scientific name & Mixture Models & Authors \\
\hline Pelagic fish and jellyfish & $\begin{array}{c}\text { Juvenile Chinook salmon (Oncorhynchus tshawytscha), } \\
\text { Three-spined stickleback (Gasterosteus aculeatus), juveniles } \\
\text { Chum salmon (O. keta), Pacific herring (Clupea pallasii), Surf } \\
\text { smelt (Hypomesus pretiosus); Sea gooseberry (Pleurobrachia } \\
\text { bachei)Water jelly (Aequorea spp.) Cross jelly (Mitrocoma } \\
\text { spp.), and Lion's mane (Cyanea capillata) }\end{array}$ & SIBER & Naman et al. (2016) \\
\hline Fin whale & Balaenoptera physalus & SIBER & Vighi et al. (2016) \\
\hline Sharks & $\begin{array}{c}\text { Bonnethead (Sphyrna tiburo), Atlantic sharpnose } \\
\text { (Rhizoprionodon terraenovae), Bull Shark (Carcharhinus } \\
\text { leucas), and White Shark (Carcharodon carcharias) }\end{array}$ & SIBER & Olin et al. (2013) \\
\hline Oyster & Crassostrea gigas & IsoSource & Leal et al. (2008) \\
\hline Crayfish & Orconectes propinquus and Orconectes rusticus & IsoSource & Taylor \& Soucek (2010) \\
\hline White shark & Carcharodon carcharias & MixSIR & Carlisle et al. (2012) \\
\hline California sea otter & Enhydra lutris nereis & MixSIR & Newsome et al. (2012) \\
\hline Common Terns & Sterna hirundo & SIAR & Bond \& Diamond (2011) \\
\hline Balearic Shearwaters & Puffinus mauretanicus & SIAR & Bond \& Diamond (2011) \\
\hline Gastropods & $\begin{array}{l}\text { Lepetodrilus elevatus, Lepetodrilus pustulosus, Lepetodrilus } \\
\text { ovalis, Eulepetopsis vitrea, Cyathermia naticoides, Peltospira } \\
\text { delicata, Peltospira operculata and Rhynchopelta concêntrica }\end{array}$ & SIAR & Gaudron et al. (2015) \\
\hline Little penguin & Eudyptula minor & SIAR & Chiaradia et al. (2014) \\
\hline Green sea turtle & Chelonia mydas & SIAR & Bezerra et al. (2015) \\
\hline Nile Tilapia & Oreochromis niloticus & MixSIAR & Moraes (2016) \\
\hline
\end{tabular}

explain that to use stable isotopes to determine the relative importance of various sources, which is equally important to understand the proportions of the sources that are less divergent in the isotopic composition. They explain that sensitivity analyses indicated that the uncertainty of estimates of the proportions are affected by the difference in signature isotopes between sources, by variability of the mixture signatures and by the size of the sample.

PHILLIPS \& KOCH (2002) demonstrated that IsoConc is based on a geometric interpretation of distance between vertices that form a mixing triangle and a triangle of food sources. In theory, there should be a visual relation on the graph between the mixing triangle and the triangle of sources, which explains whether there is a relationship or not between the consumer and each food item. Using the program, the authors realized that the IsoConc model corresponded successfully to the known proportions of food sources in relation to the species used in the research. ROBBINS et al. (2002) justify that the use of this type of model is a multi-step process, with increased numbers of assumptions and contributions factors to provide. However, KOCH \& PHILLIPS (2002) argue that a simple model is just as likely to produce errors as a more complex model. In addition, mixing models that are statistically more complex are highly sensitive to possible variations on the discrimination factors used (BOND \& DIAMOND, 2011).

PHILLIPS et al. (2014) explain, based on the original IsoConc model, that the concentration dependence of the isotopic elements was incorporate in SIAR, in IsotopeR, MixSIAR and FRUITS. For this reason, these authors showed that, when stable isotope analyses are performed, elemental concentrations are also determined (so researchers should make sure to request these data from the laboratory) to consider the dependence of concentration and make it possible to use the models.

HOPKINS \& FERGUSON performed tests of comparative application between Isotope R and the Bayesian models IsoError, IsoConc, IsoSource, SIAR and MixSIR. They concluded that the interface of Isotope R (in R) provides researchers with a tool for analysis using mixture of models with stable isotopes (SIMMs) and that the model is also applicable for use in paleontology, archeology and forensic studies, as well as for estimating pollutants. KADOYA et al. (2012) concluded that the IsoWeb model, in general, it provides a promising method 
for the reconstruction of quantitative food webs from stable isotope information. However, these authors showed that the current version of IsoWeb does not estimate a network of energy flow, and that it is necessary to develop a structure that can determine a power flow network integrating stable isotopes and other information, such as biomass and metabolic rate of each species.

According to KARNOVSKY et al. (2012), the SISUS mixing model (Stable Isotope Sourcing using Sampling) is a model with frequentbased option. This model considers the rate of discrimination (fractionation), concentration and assimilation efficiency (ERHARDT, 2014).

JACKSON et al. (2011) in turn, described the SIBER (Stable Isotope Bayesian Ellipses in $\mathrm{R})$ as a metric model that analyzes the isotope dataset based on Bayesian ellipses. FRUITS (Food Reconstruction Using Isotopic Transferred Signals) is presented as a model capable of manipulating dietary routing that makes it possible to provide a platform that simplifies the incorporation a priori information, including information from ecological, archaeological, biochemical or physiological sources (FERNANDES et al., 2014).

To make estimates on the relative contribution of food items more concretely using mixture models, HEALY et al. (2017) developed the DEsiR (Discrimination Estimation in $R$ ) which is still defined as SIDER (HEALY, 2017). The DEsiR estimates the discriminant rates and includes the functionality to consider the associated error in the construction of phylogenetic branching using the mulTree package (GUILLERME, 2016). These authors tested this model using values of the $\mathrm{C}$ and $\mathrm{N}$ isotopic ratios for different species of birds and mammals, which makes it possible for other researchers to make estimates for groups and species not yet studied.

In their research, NEWSOME et al. (2012) argued that this mixing models used a linear framework to determine a unique mathematical solution for the relative contributions of " $n+1$ " prey sources using " $\mathrm{n}$ " isotope systems (e.g., $\delta^{13} \mathrm{C}$ or $\delta^{15} \mathrm{~N}$, or both). When evaluating the applicability of one of these models, BENSTEAD et al. (2006) performed tests about contributions from food sources in a mangrove region using IsoSource. They described a statistical model that calculates the contributions in intervals, being useful to demonstrate when a source is not important for a food web. NEWSOME et al. (2012) clarified that Bayesian models, such as MixSIR and SIAR, were developed with the constructive capacity of IsoSource and allowed users to include information on isotope variation in potential sources and trophic factors of discrimination,and allowed the input of prior information of resources or habitat use. However, HOPKINS \& FERGUSON (2012) explained that; although, MixSIR can calculate dietary estimates, it may present very narrow intervals, because the model did not explain the variation between individuals and other sources of error.

Latest models such as SIAR and MixSIR implement a Bayesian approach to mixing models with stable isotopes, and allowed users to incorporate variability in discrimination factors $(\Delta)$ or even in the values of the isotopic ratios $(\delta)$ between prey and consumers (BOND \& DIAMOND, 2011). But the recent MixSIAR model allowed incorporation of hierarchical population structure and other continuous variables in the estimation of assimilated items by consumers (PHILLIPS et al., 2014), in addition to allowing the use of discriminant rates for different food items. This model is an enhanced version resulting from the contribution of researchers who had already developed other models such as MixSIR and SIAR, and, consequently, incorporates the criteria and advances of previous models.

These current Bayesian blend models employ one resampling to determine the probability of contributions from potential sources (NEWSOME et al., 2010; 2012). In general, for each source a proportional contribution vector random is proposed, from a complete set of sources (WARD et al., 2011). This type of statistical approach occurs in the MixSIAR model, for example, which uses the Monte Carlo method based on a posteriori simulations by Markov chains (MCMC). Markov chains are defined as stochastic processes that have the purpose of modeling systems and describing the probabilistic movement between a series of data through simulations (ALBERT, 2009).

When the chains are initiated at different locations in the state-space vector, each chain will converge to its equilibrium distribution or stationary distribution, which can be observed through convergence tests (GAMERMAN \& LOPES, 2006). According to STOCK \& SEMMENS(2013), MixSIAR showed three of these tests: GEWEKE (1992), GELMAN-RUBIN (1992) and HEIDELBERGERWELCH (1983). The convergence evaluated by the method of GEWEKE (1992) performed a division of variables generated by simulation, with respect to the two means in the quantiles $(0.1$ and 0.5$)$. Thus, this test used the comparison of the initial and final values of the Markov chain to verify convergence faults; 
therefore, with the hypothesis of nullity tested, values of probability below 0.05 indicated evidence contrary to the convergence of chains (BORBA et al., 2011).

For the GELMAN-RUBIN test, (GELMAN-RUBIN, 1992; GELMAN et al., 2014) scale reduction factor " $\mathrm{R}$ " can be used as an indicator of convergence. GELMAN \& RUBIN (1992) and GELMAN et al. (2014) determine if there has been convergence for values using the following rule: $1 \leq \mathrm{R} \leq 1$.1. In addition, if the values of $\mathrm{R}$ are greater than 1.1 , it is necessary to execute the process of tracking by chains again in order to improve the convergence of the data set, and to perform a better evaluation of the data used in the research.

The HEIDELBERGER-WELCH (1983) diagnostic test, evaluates the null hypothesis of stationarity of chains using two simultaneous tests. If the null hypothesis is rejected, for a given value, the test is repeated after discarding the $10 \%$ of the initial values of the sequence. If the hypothesis is rejected again, plus $10 \%$ of the initial values are discarded and thus successively until they discarded the $50 \%$ of the initial values (DELFINO et al., 2011). However, DELFINO et al., (2011) explained that if the hypothesis is rejected again, it indicated that a larger number of iterations is required. Otherwise, the initial number of iterations discarded indicated as the "burn-in" size. According to these authors, if one considers that a sequence of values sampled has reached the stationarity, the HalfWidth test should be applied to verify the estimated average being calculated with a pre-specified accuracy and, thereby, convergence will be guaranteed when the null hypothesis is accepted in both tests.

\section{CONCLUSION}

The ${ }^{13} \mathrm{C}$ and ${ }^{15} \mathrm{~N}$ isotopes and mixing models have been used successfully in several studies that aim to determine the type of diet consumed and the trophic level of aquatic organisms. However, it is essential that all data inserted in these models (discriminant factor, information on the aquatic ecosystem, species and its food sources) are obtained and properly determined in accordance with the previously defined objectives. In this context, the use of these tools enables: (I) a better understanding of the real contribution of food items (natural, artificial, autochthonous and/or allochthonous) in the nutrition of aquatic organisms, (II) adequate understanding of biology and ecology of the species studied and (III) establishment of interactions and trophic relationships between groups and species in their habitat. We concluded that application of the technique of stable isotopes with the application of mixing models composes an efficient tool to understand how aquatic organisms use food resources in their natural environment or in the cultivation environment, and how they contribute to its growth and development at different stages of life.

In animal nutrition, it becomes increasingly necessary to develop new research that includes isotopic analyses in conjunction with other types of chemical markers, especially environmental impact analyses, such as how to quantify concentrations of heavy metals based on the food ecology of a species. There will be a progressive increase in the application of mixing models as authors have become more selective and increasingly consider the inherent problems of the method. Among these problems, there is the problem of isotopic memory, related to the turnover rates and the different sources of variation that influence discriminant rates, and in the fractionation factor. Thus, consider the inherent problems of the method, ensures the reliability in the data analysis and in the results obtained by these researches.

\section{ACKNOWLEDGEMENTS}

The authors acknowledge the Fundacão de Amparo a Pesquisa do Estado do Rio Grande do Norte (FAPERN), Conselho Nacional de Desenvolvimento Científico e Tecnológico (CNPq) and Coordenacão de Aperfeiçoamentode Pessoal de Nível Superior (CAPES) for the financial support and the scholarships.

\section{DECLARATION OF CONFLICTING INTERESTS}

The authors declare no conflict of interest. The founding sponsors had no role in the design of the study; in the collection, analyses, or interpretation of data; in the writing of the manuscript, and in the decision to publish the results.

\section{REFERENCES}

ABIMORAD, E. G.; CASTELLANI, D. Nutritional requirements from amino acids to lambari yellow tail based on the composition of the carcass and of muscle. Boletim do Instituto de Pesca, v.37, n.1, p.31-38, 2011. Available from: <http://www.pesca.sp.gov.br/37_ p1_31-38.pdf $>$. Accessed: Jan. 15, 2014. ISSN: $<1678-2305>$.

ALBERT, J. Bayesian Computation with R (Use R!). $2^{\text {a }}$ ed. Springer, 304 p. 2009.

BENSTEAD, J.; et al. Testing IsoSource: Stable isotope analysis of a tropical fishery with diverse organic matter sources. Ecology, v.87, n.2, pp.326-333, 2006. Available from: <https://darchive. mblwhoilibrary.org/handle/1912/4672>. Accessed: Aug. 26, 2014. doi: 10.1890/05-0721.

BISI, T. L.; et al. Feeding ecology of marine mammals: Methods of study. Oecologia Australis, v.16, n.2, p.210-234, Junho 
2012. Available from: <http://inct.cnpq.br/web/inct-inpetam/ artigos-publicados $>$. Accessed: Mar. 14, 2014. doi: http://dx.doi. org/10.4257/oeco.2012.1602.04.

BOECKLEN, W. J.; et al. On the use of stable isotopes of trophic ecology. Annual Review of Ecology and Evolution and Systematics, v.42, p. 411 - 440, 2011. Available from: $<$ http://www.annualreviews.org/doi/abs/10.1146/annurevecolsys-102209-144726>. Accessed: Jun. 21, 2015. doi: 10.1146/ annurev-ecolsys-102209-144726.

BEZERRA, M. F.; et al. Food preferences and $\mathrm{Hg}$ distribution in Chelonia mydas assessed by stable isotopes. Environmental Pollution, v. 206, p. 236-246, 2015. Available from: $<\mathrm{http}: / / \mathrm{www}$.sciencedirect.com/science/article/pii/ S0269749115003449?via\%3Dihub>. Accessed: Sept. 5, 2016. doi: 10.1016/ j.envpol.2015.07.011.

BOND, A. L.; DIAMOND, A.W. Recent Bayesian stable-isotope mixing models are highly sensitive to variation in discrimination factors. Ecological Applications, v.21, n.4, pp.1017-1023, 2011. Available from: <http://onlinelibrary.wiley.com/doi/10.1890/092409.1/abstract>. Accessed: Nov. 27, 2014. doi: 10.1890/09-2409.1.

BORBA, L. H. F.; et al. Genetic parameters for growth and reproductive traits of Canchim breed. Pesquisa Agropecuária Brasileira - PAB, Brasília, v.46, n.11, p.1570-1578, 2011. Available from: $\quad<$ http://www.scielo.br/scielo.php?script=sci arttext\&pid=S0100-204X2011001100020>. Accessed: Jul. 17, 2017. doi: 10.1590/S0100-204X2011001100020.

BRITO, J. M.; et al. Polyculture of tilápias (Oreochromis niloticus) and Marine Shrimp (Litopenaeus vannamei) in cages - review. Revista Eletrônica Nutritime, v.11, n.02, p.3225-3237, 2014. Available from: <http://www.nutritime.com.br/arquivos internos/ artigos/ARTIGO235.pdf $>$. Accessed: Jan. 2, 2015. ISSN: 1983-9006.

BRITTON, J. R.; et al. Status, ecology and conservation of an endemic fish, Oreochromis niloticus baringoensis, in Lake Baringo, Kenya. Aquatic Conservation: Marine and Freshwater Ecosystems, v.19, p.487-496, 2009. Available from: <http:// onlinelibrary.wiley.com/doi/10.1002/aqc.998/abstract $>$. Accessed: Dec. 05, 2013. doi: 10.1002/aqc.998.

CABANELLAS-REBOREDO, M.; DEUDERO, S.; BLANCO, A. Stable-isotope signatures $\left(\delta^{13} \mathrm{C}\right.$ and $\left.\delta{ }^{15} \mathrm{~N}\right)$ of different tissues of Pinna nobilis Linnaeus, 1758 (Bivalvia): isotopic variations among tissues and between seasons. Journal of Molluscan Studies, v.75, p.343-349, 2009. Available from: <https://academic.oup.com/ mollus/article/75/4/343/1096332>. Accessed: Oct. 11, 2014. doi 10.1093/mollus/eyp021.

CALDARA,F.R.; etal. Glutamine and carbonturnoveroftheintestinal mucosa of weaned piglets. Revista Brasileira de Zootecnia, v.39, n.12, p.2664-2669, 2010. Available from: <http://www.scielo.br/ scielo.php?script=sci_arttext\&pid=S1516-35982010001200015>. Accessed: Nov. 17, 2014. doi: 10.1590/S1516-35982010001200015. ISSN: ISSN 1806-9290.

CARABALlO, P.; et al. Population growth and stable isotope analyses of Diaphanosoma spinolosum and Ceriodaphnia cornuta (Crustacea: Cladocera) fed with different seston size fractions. Acta Scientiarum. Biological Sciences, Maringá, v.33, n.1, p.1119, 2011. Available from: <http://periodicos.uem.br/ojs/index.php/ ActaSciBiolSci/article/view/7260>. Accessed: Mar. 08, 2014. doi: 10.4025/actascibiolsci.v33i1.7260.
CARLISLE, A. B.; et al. Using Stable Isotope Analysis to Understand the Migration and Trophic Ecology of Northeastern Pacific White Sharks (Carcharodon carcharias). PLOSONE, v.7, Issue 2, p.1-15, 2012. Available from: <http://journals.plos.org/ plosone/article?id=10.1371/journal.pone.0030492>. $\quad$ Accessed: Jul. 23, 2014. doi: 10.1371/journal.pone. 0030492.

CAUT, S.; ANGULO, E. E COURCHAMP, F. Variation in discrimination factors $\left(\delta^{15} \mathrm{~N}\right.$ and $\left.\delta^{13} \mathrm{C}\right)$ : the effect of diet isotopic values and applications for diet reconstruction. Journal of Applied Ecology, v.46, p.443-453, 2009. Available from: <http:// onlinelibrary.wiley.com/doi/10.1111/j.1365-2664.2009.01620.x/ abstract>. Accessed: Feb. 05, 2014. doi: 10.1111/j. 13652664.2009.01620.x

CHEN, G.; et al. Stable isotope enrichment in muscle, liver, and whole fish tissues of brown-marbled groupers (Epinephelus fuscoguttatus). Ecological Processes, v.1:7. p.1-5. 2012. Available from: <https://link.springer.com/article/10.1186/2192-1709-1-7>. Accessed: Jul. 22, 2014. doi: 10.1186/2192-1709-1-7.

CHIARADIA, A.; et al. Searching for the True Diet of Marine Predators: Incorporating Bayesian Priors into Stable Isotope Mixing Models. PLOSONE, v.9, n.3, p.1-5, 2014. Available from: $<$ http:// journals.plos.org/plosone/article?id=10.1371/journal.pone.0092665>. Accessed: Nov. 17, 2016. doi: 10.1371/journal.pone.009 2665.

CHOUVELON, T.; et al. Species-and size-related patterns in stable isotopes and mercury concentrations in fish help refine marine ecosystem indicators and provide evidence for distinct management units for hake in the Northeast Atlantic. Journal of Marine Science Advance Access, ICES Journal of Marine Science, Volume 71, Issue 5. Pages 1073-1087. August 2014. Available from: <https:// academic.oup.com/icesjms/article/71/5/1073/644162>. Accessed: May 5, 2015. doi: 10.1093/icesjms/fst199.

CORRÊA, F.; SILVA, G. C. Feeding habit of Astyanax asuncionensis (Géry 1972) during a period of full and drought, in the Stream Onça, Coxim, Mato Grosso do Sul State. Brazilian Journal of Biosciences, v.8, n.4, p.368-372, 2010. Available from: <http:// docplayer.com.br/48622620-Artigo-habito-alimentar-de-astyanaxasuncionensis-gery-1972-durante-um-periodo-de-seca-e-cheia-nocorrego-do-onca-coxim-mato-grosso-do-sul.html $>$. Accessed: Jun. 3, 2014. ISSN: 1980-4849 (on-line)/1679-2343 (print).

DELFINO, A. C. S.; et al. Bayesian analysis toxicity and interference in trials of serial dilutions. Revista Brasileira de Biometria, v.29, n.2, p.325-341, 2011. Available from: <http:// jaguar.fcav.unesp.br/RME/fasciculos/v29/v29_n2/indice_v29_ n2.php>. Accessed: Mar. 19, 2014. Electronic ISSSN: 1983-0823.

DENIRO, M. J.; EPSTEIN, S. Mechanism of carbon isotope fractionation associated with lipid synthesis. Science, v.197, p.261-263, 1977. Available from: <https://www.researchgate. net/publication/22809383_Mechanism_of_Carbon_Isotope Fractionation_Associated_with_Lipid_Synthesis $>$. Accessed: Jan. 24, 2014. doi: 10.1126/science.3 27543.

DENIRO, M.; EPSTEIN, S. Influence of diet on the distribution of carbon isotopes in animals. Geochimica et Cosmochimica Acta, v.42, p.495-506, 1978. Available from: $<$ https://www.sciencedirect. com/science/article/pii/0016703778901990>. Accessed: Jan. 24, 2 014. doi: 10.1016/0016-7037(78)90199-0.

DENIRO, M.; EPSTEIN, S. Influence of diet on the distribution of nitrogen isotopes in animals. Geochimica et Cosmochimica Acta, 
v.45, p.341-351, 1981. Available from: $<$ https://www.sciencedirect. com/science/article/pii/0016703781902441>. Accessed: Jan. 24, 2 014. doi: 10.1016/0016-7037(81)90244-1.

DUCATTI, C. Stable isotopes in aquaculture. Revista Brasileira de Zootecnia, v.36, suplemento especial, p.01-10, 2007. Available from: $<$ http://www.scielo.br/scielo.php?script=sci_artt ext\&pid=S1516-35982007001000001>. Accessed: Jan. 24, 2014. doi: 10.1590/S1516-35982007001000001.

ENDJAMBI, T.; IITEMBU, J. A.; NASHIMA, F. P. Trophic relationships of three deep-sea crustacean species (Aristeus varidens, Plesionika martia and Funchalia woodwardi) off Namibia. International Science and Technology Journal of Namibia (ISTJN), v.7, p.3-13, 2016. Available from: <http:// repository.unam.edu.na/handle/11070/1752>. Accessed: Mar. 16, 2017. ISSN: 2026-7673.

ERHARDT, E. B. Stable Isotope Sourcing using Sampling Getting Started (SISUS). Available from: <http://StatAcumen. com/sisus>. Accessed: Nov. 27, 2014.

FANTLE, M. S.; et al. A food web analysis of the juvenile blue crab, Callinetes sapidus using stable isotopes in whole animals and individual aminoacids. Oecologia, v.120, p.416-426, 1999. Available from: <https://link.springer.com/article/10.1007/s004420050874>. Accessed: Dec. 23, 2014. doi: 10.1007/s004420050874.

FIOD, M. S. R.; et al. Effect of food frequency about growth and isotopic composition $\left(\delta^{13} \mathrm{C}\right.$ and $\left.\delta^{15} \mathrm{~N}\right)$ of juveniles of Pacu Piaractus Mesopotamicus. Nucleus Animalium, v.2, n.2, p. 41-52. Nov. 2010. Available from: <http://docplayer.com.br/54568721-Efeito-dafrequencia-alimentar-sobre-o-crescimento-e-a-composicao-isotopicad-13-c-e-d-15-n-de-juvenis-de-pacu-piaractus-mesopotamicus.html> . Accessed: Feb. 8, 2014. doi: 10.3738/1982. 2278.

FINLAY, J. C.; KENDALL, C. Stable isotope tracing of temporal and spatial variability in organic matter sources to freshwater ecosystems. $10^{\circ}$ Capítulo. In: MICHENER, R.; LAJTHA, K. Stable Isotopes in Ecology and Environmental Science. $2^{\mathrm{a}}$ ed. Blackwell Publishing. 594p. 2007. Available from: $<$ http://onlinelibrary.wiley. com/doi/10.1002/9780470691854.ch10/summary>. Accessed: Jan. 26, 2014. doi: 10.1002/9780470691854.ch10.

FOCKEN, U.; BECKER, K. Metabolic fractionation of stable carbon isotopes: implications of different proximate compositions for studies of the aquatic food webs using $\delta^{13} \mathrm{C}$ data. Oecologia, v.115, p.337-343, 1998. Available from: <https://www.ncbi. nlm.nih.gov/pubmed/28308424 >. Accessed: Jan. 26, 2014. doi: $10.1007 / \mathrm{s} 004420050525$.

FRANCO,M.A.L.; etal.Arevision on the use of multiple tools for trophic studies of fish communities. Neotropical Biology and Conservation, v.9, n.3, p.172-185, September-December 2014. Available from: $<$ https://dialnet.unirioja.es/servlet/articulo? codigo $=5521029>$. Accessed: Apr. 23, 2015. ISSN 1809-9939.

FERNANDES, R.; et al. Food reconstruction using isotopic transferred signals (FRUITS): A Bayesian model for diet reconstruction. PLOSONE, v.9, n.2, p.1-9, 2014. Available from: <http://journals.plos.org/plosone/article?id=10.1371/ journal.pone.0087436>. Accessed: May 29, 2015. doi: 10.1371 / journal.pone.0087436.

FRY, B.; et al. Trophic position and individual feeding histories of fish from Lake Okeechobee, Florida. Canadian Journal of Fisheries and Aquatic Sciences, v.56, p.590-600, 1999. Available from: <http://www.nrcresearchpress.com/doi/ abs/10.1139/f98-204\#.WoyX5nwVjIU>. Accessed: Sept. 12, 2014. doi: 10.1139/f98-204.

FRY, B. Stable Isotope Ecology. Department of Oceanography and Coastal Sciences. Coastal Ecology Institute. School of the Coast and Environment. Springer. 316p. 2006.

FRY, B. Stable Isotope Ecology. Library of Congress. Printed in the United States of America. Springer Science-Business Media, LLC. $3^{\text {rd }}$ printing, 2008.

GAMBOA-DELGADO, J.; LE VAY, L. Artemia replacement in co-feeding regimes for mysis and postlarval stages of Litopenaeus vannamei: Nutritional contribution of inert diets to tissue growth as indicated by natural carbon stable isotopes. Aquaculture, v.297, p.128-135, 2009a. Available from: <https://www.sciencedirect. com/science/article/abs/pii/S0044848609007844>. Accessed: Aug. 2, 2014. doi: 10.1016/j.aquaculture.2009.09.009.

GAMBOA-DELGADO, J.; LE VAY, L. Natural stable isotopes as indicators of the relative contribution of soy protein and fish meal to tissue growth in Pacific white shrimp (Litopenaeus vannamei) fed compound diets. Aquaculture, v.291, p.115-123, 2009b. Available from: <https://www.sciencedirect.com/science/article/ abs/pii/S0044848609002452>. Accessed: Jun. 14, 2014. doi: 10.1016/j.aquaculture.2009.03.012.

GAMBOA-DELGADO, J; ; et al. Simultaneous estimation of the nutritional contribution of fish meal, soy protein isolate and corn gluten to the growth of Pacific white shrimp (Litopenaeus vannamei) using dual stable isotope analysis. Aquaculture. v.380383, p.33-40, 2013. Available from: <https://www.sciencedirect. com/science/article/abs/pii/S0044848612007041>. Accessed: jan. 15, 2014. doi: /10.1016/j.aquaculture.2012.11.028.

GAMBOA-DELGADO, J.; et al. Application of stable isotope analysis to differentiate shrimp extracted by industrial fishing or produced through aquaculture practices. Canadian Journal of Fisheries and Aquatic Sciences, v.71, p.1520-1528, 2014. Available from: <http://www.nrcresearchpress.com/doi/ abs/10.1139/cjfas-2014-0005\#.Woyj nwVjIU>. Accessed: Feb. 11, 2015. doi: $10.1139 /$ cjfas-2014-0005.

GAMERMAN, D.; LOPES, H. L. Markov Chain Monte Carlo: Stochastic Simulation for Bayesian Inference. Second Edition. Taylor \& Francis, New York. 343p. 2006.

GANNES, L. Z.; MARTINEZ DEL RIO, C.; KOCH, P. Natural Abundance Variations in Stable Isotopes and their Potential Uses in Animal Physiological Ecology. Comparative Biochemistry and Physiology, v.119A, n.3, pp.725-737, 1998. Available from: $<$ https://www.sciencedirect.com/science/article/pii/ S1095643398010162>. Accessed: Aug. 26, 2014. doi: 10.1016/ S1095-6433(98)01016-2.

GAUDRON, S. M.; et al. How are microbial and detrital sources partitioned among and within gastropods species at East Pacific Rise hydrothermal vents? Marine Ecology, v.36 (Suppl. 1), p.18-34, 2015. Available from: <http://onlinelibrary.wiley.com/ doi/10.1111/maec.12260/abstract $>$. Accessed: Nov. 11, 2016. doi: 10.1111/maec. 12260 .

GELMAN, A.; RUBIN, D. B. A single series from the Gibbs sampler provides a false sense of security. In: Bernardo, J.M., Berger, J.O., 
Dawid, A.P., Smith, A.F.M. (Eds.), Bayesian Statistics, Vol. 4. Oxford University Press, Oxford, 1992. p.625-631.

GELMAN, A.; et al. Texts in Statistical Science. Bayesian Data Analysis. Chapman \& Hall/CRC editora. $3^{\mathrm{a}}$ ed, 2014. 656 p.

GERMAN, D. P.; MILES, R. D. Stable carbon and nitrogen incorporation in blood and fin tissue of the catfish Pterygoplichthys disjunctivus (Siluriformes, Loricariidae). Environmental Biology of Fishes, v.89, p.117-133, 2010. Available from: <https://link. springer.com/article/10.1007/s10641-010-9703-0>. Accessed: Nov. 27, 2014. doi: 10.1007/s10641-010-9703-0.

GEWEKE, J. Evaluating the accuracy of sampling-based approaches to the calculation of posterior moments. In: Bernardo, J.M., Berger, J.O., Dawid, A.P., Smith, A.F.M. (Eds.), Bayesian Statistics, Vol. 4. Oxford University Press, Oxford, 1992. p.169-193.

GONDWE, M. J.; GUILDFORD, S. J.; HECKY, R. E. Physicalchemical measurements in the water column along a transect through a tilapia cage fish farm in Lake Malawi, Africa. Journal of Great Lakes Research, v.37, n.1, p.102-113,2011. Available from: <https:// www.sciencedirect.com/science/article/pii/S0380133010002066>. Accessed: Jun. 17, 2015. doi: 10.1016/ j.jglr.2010.10.001.

GONDWE, M. J.; GUILDFORD, S. J.; HECKY, R. E. Tracing the flux of aquaculture-derived organic wastes in the southeast arm of Lake Malawi using carbon and nitrogen stable isotopes. Aquaculture, v. 350-353, p.8-18, 2012. Available from: <https://www.sciencedirect. com/science/article/abs/pii/S0044848612002694>. Accessed: Jun. 17, 2015. doi: 10.1016/j.aquacultu re.2012.04.030.

GUILLERME, T. mulTree manual. 5 p. January 21, 2016 Available from: <https://github.com/TGuillerme/mulTree $>$. Accessed: Feb. 10, 2016

HEALY K.; et al. Predicting trophic discrimination factor using Bayesian inference and phylogenetic, ecological and physiological data. DEsiR: Discrimination Estimation in R. PeerJ Preprints, v.5, p. 1-21. 2017. Available from: <https://peerj.com/preprints/1950/> Accessed: Nov. 19, 2017. doi: 10.7287/peerj.preprints.1950v3.

HEALY, K. Introduction to SIDER. 7 p. 2017. Available from: $<$ http://cran.r-project.Org/web/packages/MCMCglmm/index. html>. Accessed: Nov. 19, 2017.

HEIDELBERGER, P.; WELCH, P. Simulation run length control in the presence of an initial transient. Operations Research, v.31, n.6, p.1109-44, 1983. Available from: <https://pubsonline. informs.org/doi/abs/10.1287/opre.31.6.1109? journalCode=opre $>$. Accessed: Aug. 25, 2015. doi: 10.1287/opre.31.6.1109.

HOBSON, K. A.; WELCH, H. E. Cannibalism and trophic structure in a high arctic lake-insights from stable isotope analysis. Canadian Journal of Fisheries and Aquatic Sciences, v.52, p.1195-1201, 1995. Available from: <http://www.nrcresearchpress. com/doi/abs/10.1139/f95-116\#.WozUEHwVjIU>. Accessed: Apr. 14, 2014. doi: 10.1139/f95-116.

HOPKINS, J. B.; FERGUSON, J. M. Estimating the Diets of Animals Using Stable Isotopes and a Comprehensive Bayesian Mixing Model. PLOSONE, v.7, n.1, p.1-13, January 2012. Available from: <http://journals.plos.org/plosone/ article? $\mathrm{id}=10.1371 /$ journal.pone.0028478>. Accessed: Mar. 22, 2014. doi: 10.1371/journal.pone. 0028478 .
JACKSON, A. L.; et al. Comparing isotopic niche widths among and within communities: SIBER-Stable Isotope Bayesian Ellipses in R. Journal of Animal Ecology, v.80, p.595-602, 2011. Available from: $<$ https://www.ncbi.nlm.nih.gov/pubmed/21401589>. Accessed: Sept. 3, 2014. doi: 10.1111/j.1365-2656.2011.01806.x.

JAOUEN, K.; SZPAK, P.; RICHARDS, M. P. Zinc Isotope Ratios as Indicators of Diet and Trophic Level in Arctic Marine Mammals. PLOSONE, March 24, v. 11(3), p.113, 2016. Available from: <http://journals.plos.org/plosone/ article?id=10.1371/journal.pone.0152299>. Accessed: Jun. 13, 2017. doi: 10.1371/journal.pone.0152299.

KADYE, W.T.; BOOTH, A. J. Integrating stomach contents and stable isotope analyses to elucidate the feeding habits of non-native sharptooth catfish Clarias gariepinus. Biological invasions, v.14, n.4, p.779-795, 2012. Available from: <https://link.springer.com/ article/10.1007/s10530-011-0116-6>. Accessed: Jul. 17, 2016. doi: 10.1007/s10530-011-0116-6.

KADOYA, T.; OSADA, Y.; TAKIMOTO, G. IsoWeb: A Bayesian Isotope Mixing Model for Diet Analysis of the Whole Food Web. PLOSONE, v.7, n.7, p., 2012. Available from: <http://journals. plos.org/plosone/article?id=10.1371/journal.pone.0041057>. Accessed: Jan. 03, 2015. doi: 10.1371/journal.pone.0041057.

KARNOVSKY, N. J.; HOBSON, K. A.; IVERSON, S. J. From lavage to lipids: estimating diets of seabirds. Marine Ecology Progress Series, v.451, p.263-284, 2012. Available from: <http:// www.int-res.com/abstracts/meps/v451/p263-284/>. Accessed: Feb. 2, 2015. doi: 10.33 54/meps09713.

KELLY, L. J.; MARTÍNEZ DEL RIO, C. The Fate of Carbon in Growing Fish: An Experimental Study of Isotopic Routing. Physiological and Biochemical Zoology, v.83, n.3, p.473480, 2010. Available from: <https://www.ncbi.nlm.nih.gov/ pubmed/20201680>. Accessed: Oct. 28, 2014. doi: 10.1086/649628.

KOCH, P. L.; PHILLIPS, D. L. Incorporating concentration dependence in stable isotope mixing models: a reply to Robbins, Hilderbrand and Farley (2002). Oecologia, v.133, p.14-18, 2002. Available from: <https://www.ncbi.nlm.nih.gov/ pubmed/24599364>. Accessed: Dec. 15, 2014. doi: 10.1007/ s00442-002-0977-6.

LEAL, J. C. M.; et al. Stable isotopes $\left(\delta^{13} \mathrm{C}, \delta^{15} \mathrm{~N}\right)$ and modelling as tools to estimate the trophic ecology of cultivated oysters in two contrasting environments. Marine Biology, v.153, n.4, p.673-688, 2008. Available from: $<$ https://link.springer.com/article/10.1007 \%2Fs00227-007-0841-7>. Accessed: Jul. 18, 2014. doi: 10.1007/ s00227-007-0841-7.

LETOURNEUR, Y.; et al. Identifying carbon sources and trophic position of coral reef fishes using diet and stable isotope $\left(\delta^{15} \mathrm{~N}\right.$ and $\delta^{13} \mathrm{C}$ ) analyses in two contrasted bays in Moorea, French Polynesia. Coral Reefs, v.32, n.4, p.1091-1102, 2013. Available from: $<$ https:// link.springer.com/article/10.1007\%2Fs00338-013-1073-6>. Accessed: Sept.6, 2016. doi: 10.1007/s00338-013-1073-6.

LI, K.; et al. Stable isotope enrichment, dietary sources and trophic overlap between silver carp (Hypophthalmichthys molitrix) and bighead carp (Aristichthys nobilis). Aquaculture, v. 402-403, p.8-12, 2013. Available from: <https://www.sciencedirect.com/ science/article/abs/pii/S0044848613001397>. Accessed: Oct. 23, 2016. doi: 10.1016/j.aquaculture.2013.03.020. 
LOCHMANN, R.; PERSCHBACHER, P. Nutritional contribution of natural and supplemental foods for Nile Tilapia: Stable carbon isotope analysis. In: K. Mcelwee, D. Burke, M. Niles, X. Cummings, and H. Egna (Editors), Seventeenth Annual Technical Report. Pond Dynamics/Aquaculture CRSP. Oregon State University, Corvallis, Oregon, 2000. p.29-31. Available from: <http:// pdacrsp.oregonstate.edu/pubs/technical/17tchhtml/8KR3A.html $>$. Accessed: Aug. 11, 2014.

LOCHMANN, R. Fish yields and economic benefits of tilapia/ clarias polyculture in fertilized ponds receiving commercial feeds or pelleted agricultural by-products. In: K. McElwee, K. Lewis, M. Nidiffer, and P. Buitrago (Editors), Nineteenth Annual Technical Report. Pond Dynamics/Aquaculture CRSP, Oregon State University, Corvallis, Oregon, 2002. p.17-20. Available from: <http://pdacrsp.oregonstate.edu/pubs/ technical/19tchhtml/9FFR2A.html>. Accessed: Aug. 11, 2014

MACAVOY, S. E.; MACKO, S. A.; GARMAN, G. C. Isotopic turnover in aquatic predators: quantifying the exploitation of migratory prey. Canadian Journal of Fisheries and Aquatic Sciences, v.58, p.923-932, 2001. Available from: <http://www. nrcresearchpress.com/doi/abs/10.1139/f01-045\#.Wozss3wVjIU>. Accessed: May 14, 2014. doi: 10.1139/f01-045.

MANETTA, G. I.; BENEDITO-CECILIO, E. The use of stable isotopes technique in the turnover estimative rate in ecological studies. Acta Scientiarum: Biological Sciences, Maringá, v.25, n.1, p.121-129, 2003. Available from: <http://www.periodicos. uem.br/ojs/index.php/ActaSciBiolSci/article/view/2090> Accessed: Mar. 19, 2014. doi: 10.4025/actascibiolsci.v25i1.2090.

MARTINELLI, L. A.; et al. Use of natural variations of $\delta^{13} \mathrm{C}$ in the study of food chains in aquatic environments: principles and perspectives. Acta Limnologica Brasiliensia, v.11, p.859882, 1988. Available from: <http://www.scielo.br/scielo. $\mathrm{php}$ ? script $=$ sci_serial\&pid $=2179-975 \mathrm{X} \& \operatorname{lng}=\mathrm{en} \& \mathrm{nrm}=\mathrm{iso}>$. Accessed: Apr. 04, 2014. Print ISSN 2179-975X.

MARTINELLI, L. A.; et al. Discovering environmental questions with stable isotopes. São Paulo: Oficina de Textos, 2009.

MARTINEZ DEL RIO, C.; et al. Isotopic ecology ten years after a call for more laboratory experiments. Biological Reviews, v.84, p91-111, 2009. Available from: <http://onlinelibrary.wiley.com/ doi/10.1111/j.1469-185X.2008.00064.x/pdf>. Accessed: Jun. 6, 2014 doi: 10.1111/j.1469-185X.2008.00064.x.

MATICH, P.; HEITHAUS, M. R.; LAYMAN, C. A. Size-based variation in intertissue comparisons of stable carbon and nitrogen isotopic signatures of bull sharks (Carcharhinus leucas) and tiger sharks (Galeocerdo cuvier). Canadian Journal of Fisheries and Aquatic Sciences, v.67, 2010. Available from: <http://www. nrcresearchpress.com/doi/abs/10.1139/F10-037\#.WoztpnwVjIU> Accessed: Sept. 04, 2015. doi: 10.1139/F10-037.

MILL, A. C.; PINNEGAR, J. K.; POLUNIN, N. V. C. Explaining isotope trophic-step fractionation: why herbivorous fish are different. Functional Ecology, v.21, p.1137-1145, 2007. Available from: <http://onlinelibrary.wiley.com/doi/10.1111/ j.1365-2435.2007.01330.x/abstract>. Accessed: Nov. 10, 2014 doi: $10.1111 / \mathrm{j} .1365-2435.2007 .01330 . x$.

MONT'ALVERNE, R.; et al. Elemental turnover rates and isotopic discrimination in a euryhaline fish reared under different salinities: Implications for movement studies. Journal of Experimental Marine
Biology and Ecology, v.480, p.36-44, 2016. Available from: $<$ https:// www.sciencedirect.com/science/article/pii/S0022098116300569>. Accessed: May 16, 2017. doi: 10.1016/j.jembe.2016.03.021.

MOORE, J. W.; SEMMENS, B. X. Incorporating uncertainty and prior information into stable isotope mixing models. Ecology Letters, v.11, p.470-480, 2008. Available from: $<$ http://onlinelibrary. wiley.com/doi/10.1111/j.1461-0248.2008.01163.x/abstract>. Accessed: Mar. 1, 2014. doi: 10.1111/j.1461-0248.2008.01163.x.

MORAES, C. R. F. de. Stable isotopes of $\mathrm{C}$ and $\mathrm{N}$ as dietary indicators of Nile Tilapia (Oreochromis niloticus) cultivated in cages in the Reservoir of the Brazilian Semiarid Region. 2016. 81 p. Master Thesis (Mestrado em Ciência Animal: Ecologia e Conservação no Semiárido) - Universidade Federal Rural do Semiárido (UEFRSA).

MURDOCH, A.; et al. Assessing the food web impacts of an anadromous Arctic charr introduction to a sub-Arctic watershed using stable isotopes. Fisheries Management and Ecology, v.20, p.302-314, 2013. Available from: <http://onlinelibrary.wiley.com/ doi/10.1111/fme.12012/abstract>. Accessed: Oct. 13, 2016. doi: $10.1111 /$ fme. 12012 .

NACHEV, M.; et al. Understanding trophic interactions in host parasite associations using stable isotopes of carbon and nitrogen. Parasites \& Vectors, v.10, p.90, 2017. Available from: <https:// parasitesandvectors.biomedcentral.com/articles/10.1186/s13071-0172030-y>. Accessed: Jul. 12, 2017. doi: 10.1186/s13071-017-2030-y.

NAMAN, S. M.; et al. Stable isotope-based trophic structure of pelagic fish and jellyfish across natural and anthropogenic landscape gradients in a fjord estuary. Ecology and Evolution, v.6, p.8159-8173, 2016. Available from: <http://onlinelibrary.wiley. com/doi/10.1002/ece3.2450/abstract>. Accessed: Jun. 17, 2017. doi: $10.1002 /$ ec e3.2450.

NEWMAN, S. J.; et al. Stock structure of blue threadfin Eleutheronema tetradactylum across northern Australia as inferred from stable isotopes in sagittal otolith carbonate. Fisheries Management and Ecology, v.18, p.246-257, 2011. Available from: <http://onlinelibrary.wiley.com/doi/10.1111/ j.1365-2400.2010.00780.x/abstract $>$. Accessed: Jan. 9.2014. doi: 10.1111/j.1365-2400.2010.00780.x.

NEWSOME, S. D.; CLEMENTZ, M. T.; KOCH, P. L. Using stable isotope biogeochemistry to study marine mammal ecology. Marine Mammal Science, v.26, n.3, p.509-572, July 2010. Available from: <http://onlinelibrary.wiley.com/doi/10.1111/ j.1748-7692.2009.00354.x/abs tract>. Accessed: May 11, 2015. doi: $10.1111 / \mathrm{j} .1748-7692.2009 .00354 . x$.

NEWSOME, S. D.; et al. Tools for quantifying isotopic niche space and dietary variation at the individual and population level. Journal of Mammalogy, v.93, n.2, p.329-341, 2012. Available from: $<$ https://academic. oup.com/jmammal/article/93/2/329/919625>. Accessed: May 11, 2015. doi: 10.1644/11-MA MM-S-187.1.

OLIN, J. A.; et al. Variable $\delta^{15} \mathrm{~N}$ Diet-Tissue Discrimination Factors among Sharks: Implications for Trophic Position, Diet and Food Web Models. PLOSONE, v.8, n.10, p.1-11, 2013. Available from: $<\mathrm{http} / /$ journals.plos.org/plosone/article?id=10.1371/journal.pone.0077567>. Accessed: Feb. 14, 2014. doi: 10.1371/journal.pone.0077567.

OVERMAN, N. C.; PARRISH, D. L. Stable isotope composition of walleye: N-15 accumulation with age and area-specific 
differences in delta C-13. Canadian Journal of Fisheries and Aquatic Sciences, v.58, p.1253-1260, 2001. Available from: $<$ http://www.nrcresearchpress.com/doi/abs/10.1139/f01-072\#. Wo0LpXwVjIU>. Accessed: Mar. 19, 2014. doi: 10.1139/f01-072.

PARNELL, A. C.; et al. Source Partitioning Using Stable Isotopes: Coping with Too Much Variation. PLOSONE, v.5, n.3, p.1-5, 2010. Available from: <http://journals.plos.org/plosone/ article?id=10.1371/journal.pone.0009672>. Accessed: Oct. 21, 2014. doi: 10.1371/journal.pone.0009672.

PARNELL, A. C.; et al. Bayesian stable isotope mixing models. Environmetrics, v.24, n.6, p.387-399, 2013. Available from: $<$ http://onlinelibrary.wiley.com/doi/10.1002/env.2221/abstract $>$. Accessed: Mar. 13, 2014 doi: 10.1002/env.2221.

PASQUAUD, S.; et al. Determination of fish trophic levels in an estuarine system. Estuarine Coastal and Shelf Science, v.86, n.2, p.237-246, 2010. Available from: <https://www.sciencedirect. com/science/article/pii/S0272771409005344>. Accessed: Jun. 17, 2015. doi: 10.1016/j.ecss.2009.11.019.

PEREIRA, L. A.; BENEDITO, E. Stable isotopes in ecological studies: methods, applications and perspectives. Revista biociências, Taubaté, v.13, n.1-2, p.16-27, Jan/Jun 2007. Available from: <http://periodicos.unitau.br/ojs-2.2/index.php/biociencias/ article/view/303>. Accessed: Feb. 16, 2014. ISSN: 1415-7411.

PESSOA, E. K. R.; et al. Anatomy and Histology of the Digestive Tract and Feeding Habits of Hoplias malabaricus (Bloch, 1794) (Osteichthyes: Erythrinidae). Animal Biology Journal, v.3, n.4, p.145-158, 2012. Available from: <https://search.proquest. com/openview/9c34d446c5eeeb183343f46f4050a15d/1?pqorigsite $=$ gscholar\&cbl=2034892>. Accessed: Apr. 7, 2015.

PESSOA, E. K. R.; et al. Feeding and reproductive aspects of the fish Hypostomus pusarum (Starks, 1913) (Osteichthyes: Loricariidae) in Marechal Dutra reservoir, Rio Grande do Norte, Brazil. Biota Amazônia, Macapá, v.3, n.3, p.45-53, 2013a. Available from: <https://periodicos.unifap.br/index.php/biota/ article/view/750>. Accessed: Aug. 23, 2014. doi: 10.18561/21795746/biotaa mazonia.v3n3p45-53.

PESSOA, E. K. R.; et al. Comparative morphology of the digestive tract of the fishes Hoplias malabaricus and Hypostomus pusarum in Marechal Dutra reservoir, Rio Grande do Norte, Brazil. Biota Amazônia, v.3, p.48- 57, 2013b. Available from: $<$ https://periodicos. unifap.br/index.php/biota/article/view/609>. Accessed: Nov. 17, 2014. doi: 10.18561/2179-5746/biotaamazonia.v3n1p 48-57.

PHILIPPSEN, J. S.; BENEDITO, E. Discrimination factor in the trophic ecology of fishes: a review about sources of variation and methods to obtain it. Oecologia Australis, v.17, n.2, p.1526, Junho 2013. Available from: < https://www.researchgate.net/ publication/284362034_fator_de_discriminacao_na_ecologia_ trofica_de_peixes_uma_revisao_sobre_as_fontes_de_variacao_e os_metodos_de_obtencao>. Accessed: Sept. 28, 2014. doi: $10.4257 /$ oeco. 2013.1702 .03 .

PHILLIPS, D. L.; GREGG, J. W. Uncertainty in source partitioning using stable isotopes. Oecologia, v.127, p.171-179, 2001. Available from: < https://link.springer.com/article/10.1007/s004420000578>. Accessed: Apr. 16, 2014. doi: 10.1007/s004420000578.

PHILLIPS, D. L. Mixing models in analyses of diet using multiple stable isotopes: a critique. Oecologia, v.127, p.166-170, 2001.
Available from: <https://www.ncbi.nlm.nih.gov/pubmed/24577645>. Accessed: Apr. 16, 2014. doi: 10.1007/s004420000571.

PHILLIPS, D. L.; KOCH, P.L. Incorporating concentration dependence in stable isotope mixing models. Oecologia, v.130, p.114-125, 2002. Available from: <https://link.springer.com/ article/10.1007/s004420100786>. Accessed: Apr. 16, 2014. doi: $10.1007 / \mathrm{s} 004420100786$.

PHILLIPS, D. L.; GREGG J. W. Source partitioning using stable isotopes: coping with too many sources. Oecologia, v.136, p.261-269, 2003. Available from: <https://link.springer.com/ article/10.1007/s00442-003-1218-3>. Accessed: Apr. 16, 2014. doi: $10.1007 / \mathrm{s} 00442-003-1218-3$.

PHILLIPS, D. L.; et al. Best practices for use of stable isotope mixing models in food-web studies. Canadian Journal of Zoology, v.92, p.823-835, 2014. Available from: <http://www.nrcresearchpress. com/doi/abs/10.1139/cjz-2014-0127\#.Wo1wa3wVjIU>. Accessed: Jun. 11, 2015. doi: 10.1139/cjz-2014-0127.

PINNEGAR, J. K.; POLUNIN, N. V. C. Differential fractionation of $\delta^{13} \mathrm{C}$ and $\delta^{15} \mathrm{~N}$ among fish tissues: implications for the study of trophic interactions. Functional Ecology, v.13, p.225-231, 1999. Available from: <http://onlinelibrary.wiley.com/doi/10.1046/ j.1365-2435.1999.00301.x/abstract>. Accessed: Oct. 9, 2014. doi: 10.1046/j.1365-2435.1999.00301.x.

PINNEGAR, J. K.; CAMPBELL, N.; POLUNIN, N. V. C. Unusual stable isotope fractionation patterns observed for fish host-parasite trophic relationships. Journal of Fish Biology, v.59, p.494-503, 2001. Available from: <https://www. researchgate.net/publication/248846754_Unusual_stable_ isotope_fractionation_patterns_observed_for_fish_hostparasite_trophic_relationships $>$. Accessed: Oct. 9, 2014. doi: 10.1006/jfbi.2001.1660.

PONSARD, S.; AVERBUCH, P. Should growing and adult animals fed on the same diet show different $\delta^{15} \mathrm{~N}$ values? Rapid Communications in Mass Spectrometry, v.13, p.1305-1310, 1999. Available from: <http://onlinelibrary.wiley.com/doi/10.1002/(SICI)10970231(19990715)13:13\%3C1305::AID-RCM654\%3E3.0.CO;2-D/ abstract $>$. Accessed: Apr. 22, 2014. doi: 10.1002/(SICI)10970231(19990715)13:13<1305::AID-RCM654>3.0.CO;2-D.

RAO, W.; et al. Size-dependent feeding of omnivorous Nile tilapiain a macrophyte-dominated lake: implicationsfor lake management. Hydrobiologia, v.749, p.125-134, 2015. Available from: <https:// link.springer.com/article/10.1007/s10750-014-2155-3>. Accessed: Sept. 4, 2015. doi: 10.1007/s10750-014-2155-3.

ROBBINS, C. T.; HILDERBRAND, G. V.; FARLEY, S. D. Incorporating concentration dependence in stable isotope mixing models: a response to Phillips and Koch. Oecologia, v.133, p.10-13, 2002. Available from: <https://www.ncbi.nlm.nih.gov/ pubmed/24599363>. Accessed: Feb. 15, 2014. doi: 10.1007/ s00442-002-0978-5.

SEMINOFF, J. A.; et al. Stable isotope discrimination $\left(\delta^{13} \mathrm{C}\right.$ and $\delta^{15} \mathrm{~N}$ ) between soft tissues of the green sea turtle Chelonia mydas and its diet. Marine Ecology Progress Series, v.308, p.271-278, 2006. Available from: <https://www.researchgate.net/ publication/250218729_Stable_isotope_discrimination_d13C and_d15N_between_soft_tissues_of_the_Green_Sea_ Turtle Chelonia_mydas_and_its_diet>. Accessed: Jul. 25, 2014. doi: 10.3354/meps308271. 
SCHROEDER, G. L. Stable isotope ratios as naturally occurring tracers in the aquaculture food web. Aquaculture, v.30, p.203-210, 1983. Available from: <https://www.sciencedirect.com/science/ article/abs/pii/004484868390162X>. Accessed: Sept. 14, 2014. doi: 10.1016/ 0044-8486(83)90162-X.

STOCK, B. C.; SEMMENS, B. X. MixSIAR GUI user manual: version 1.0. 2013. Available from: $<$ http://conserver.iugo-cafe.org/ user/brice.semmens/MixSIAR>. Accessed: Jan. 17, 2015.

SUZUKI, K.W.; et al. Differential isotopic enrichment and half-life among tissues in Japanese temperate bass (Lateolabrax japonicus) juveniles: implications for analyzing migration. Canadian Journal of Fisheries and Aquatic Sciences, v.62, p.671-678, 2005. Available from: <http://www.nrcresearchpress.com/doi/ abs/10.1139/f04-231\#.Wo2INnwVjIU>. Accessed: Apr. 15, 2014. doi: $10.1139 /$ f04-231.

TAYLOR, C. A.; SOUCEK, D. J. Re-examining the importance of fish in the diets of stream-dwelling Crayfishes: Implicationsfor food web analyses and conservation. The American Midland Naturalist, v.163, n.2, p.280-293, 2010. Available from: <http:// www.bioone.org/doi/abs/10.1674/0003-0031-163.2.280>. Accessed: Oct. 16, 2014. doi: 10.1674/0003-0031-163.2.280.

TOMINAGA, O.; UNO, N.; SEIKAI, T. Influence of diet shift from formulated feed to live mysids on the carbon and nitrogen stable isotope ratio $\left(\mathrm{d}^{13} \mathrm{C}\right.$ and $\left.\mathrm{d}^{15} \mathrm{~N}\right)$ in dorsal muscles of juvenile Japanese flounders, Paralichthys olivaceus. Aquaculture, v.218, p.265-276, 2003. Available from: <https://www.sciencedirect.com/ science/article/abs/pii/S0044848602004969>. Accessed: Dec. 20, 2014. doi: 10.1016/S0044-8486(02)00496-9.

TIUNOV, A.V. Stable isotopes of carbon and nitrogen in soil ecological studies. Biology Bulletin, v.34, n.4, p.395-407, 2007. Available from: $<$ https://link.springer.com/article/10.1134/S1062359007040127>. Accessed: May 5, 2014. doi: 10.1134/S1062359007040127.

VANDERKLIFT, M. A., PONSARD, S. Sources of variation in consumer-diet delta N-15 enrichment: a meta-analysis. Oecologia, v.136, p.169-182, 2003. Available from: <https://www.ncbi. nlm.nih.gov/pubmed/12802678>. Accessed: Nov. 26, 2014. doi: $10.1007 / \mathrm{s} 00442-003-1270-\mathrm{z}$.

VANDER ZANDEN, M. J.; CABANA, G.; RASMUSSEN, J. B. Primary Consumer $\mathrm{d}^{13} \mathrm{C}$ and $\mathrm{d}^{15} \mathrm{~N}$ the trophic position of aquatic consumers. Ecology, v.80, n.4, p.395-1404, 1999. Available from: $\quad<$ https://www.researchgate.net/publication/201170246 Primary_consumer_DC_and_DN_and_the_trophic_position_ of aquatic_consumers $>$. Accessed: Feb.19, 2015. doi: 10.1890/ 0012-9658(1999)080[1395:PCCANA]2.0.CO;2.

VIGHI, M.; BORRELL, A.; AGUILAR, A. Stable isotope analysis and fin whale subpopulation structure in the eastern
North Atlantic. Marine Mammal Science, v.32, n.2, p.535551. April 2016. Available from: <http://onlinelibrary.wiley. com/doi/10.1111/mms.12283/pdf>. Accessed: Jun. 3, 2017, doi: $10.1111 / \mathrm{mms} .12283$

WARD, E. J.; et al. A quantitative approach to combine sources in stable isotope mixing models. February. Echosphere, v.2, n.2, p1-11, 2011. Available from: <http://onlinelibrary.wiley.com/ doi/10.1890/ES10-00190.1/abstract>. Accessed: Oct. 22, 2015. doi: 10.1890/ES10-00190.1.

WOLF, N.; CARLETON, S. A.; MARTINEZ DEL RIO, C. Ten years of experimental animal isotopic ecology. Functional Ecology, 2014. doi: 10.1111/j.1365-2435.2009.01529.x.

XIA, B.; et al. Uptake of farming wastes by silver carp Hypophthalmichthys molitrix in polyculture ponds of grass carp Ctenopharyngodon idella: Evidence from $\mathrm{C}$ and $\mathrm{N}$ stable isotopic analysis. Aquaculture, v.404-405, p.8-14, 2013. Available from: <https://www.sciencedirect.com/science/article/abs/pii/ S0044848613001774>. Accessed: May 19, 2014. doi: 10.1016/j. aquaculture.2013.04.012

XU, X.; ZHANG, Q.; WANG, W. X. Linking mercury, carbon, and nitrogen stable isotopes in Tibetan biota: Implications for using mercury stable isotopes as source tracers. Scientific Reports, v.6, n.25394, p.1-10, 2016. Available from: <https:// www.ncbi.nlm.nih.gov/pubmed/27151563>. Accessed: Apr. 23, 2017. doi: $10.1038 /$ srep25394.

ZORZAL-ALMEIDA, S.; FERNANDES, V. O. The influence of the predation of tilapia (Oreochromis sp.) in the periphytic algae community structure in a tropical pisciculture pond. Neotropical Biology and Conservation, v.9, n.1, p.4954, January-April 2014. Available from: <https://www. researchgate.net/publication/264196508Influencia_da_ predacao_de_tilapia_Oreochromis_sp_na_estrutura da_comunidade_de_algas_perifiticas_em_tanque_de piscicultura_tropical $>$. Accessed: Nov. 22, 2015. doi: $10 . \overline{4013 /}$ nbc. 2014.91. 06 .

ZUANON, J. A. S. Turnover de carbono em tecido muscular de alevinos de tilápia do Nilo (Oreochromis nilloticus) por meio dos isótopos estáveis de carbono (13C/12C). Tese (Doutorado). Jaboticabal. Universidade Estadual Paulista - UNESP. 96 p. 2003.

ZUANON, J. A. S.; et al. Muscle $\delta^{13} \mathrm{C}$ change in Nile tilapia (Oreochromis niloticus) fingerlings fed on C3- or C4-cycle plants grain-based diets. Comparative Biochemistry and Physiology Part A: Molecular \& Integrative Physiology, v.147, p.761-765, 2007. Available from: <https://www.sciencedirect.com/science/ article/pii/S1095643306003795>. Accessed: Nov. 22, 2015. doi: 10.1016/j.cbpa.2006.08.038. 


\section{Erratum}

In the article "Mixing models and stable isotopes as tools for research on feeding aquatic organisms" published in Ciência Rural, volume 48, number 7, DOI http://dx.doi.org/10.1590/0103-8478cr20160101.

In the INTRODUCTION, where we read:

Furthermore, the quantity and quality of the assimilated food influence the allocation of nutrients to animal tissues and organs (SAMPAIO et al., 2001).

Read:

Furthermore, the quantity and quality of the assimilated food influence the allocation of nutrients to animal tissues and organs (ZUANON, 2003).

In the REFERENCES, where we read:

SAMPAIO, F. G. Apparent digestibility by Nile tilapia Oreochromis niloticus (L.) of Brazilian-made meal, imported fish meal and toasted and spray-dried blood. Acta Scientiarum, Maringá, v.23, n.4, p.891-896, 2001. Available from: <http://eduem.uem.br/ojs/index.php/ActaSciAnimSci/article/view/2642/2162>. Accessed: Mar. 30, 2014. ISSN 1806-2636 (impresso) e ISSN 1807-8672 (on-line).

Read:

ZUANON, J. A. S. Turnover de carbono em tecido muscular de alevinos de tilápia do Nilo (Oreochromis nilloticus) por meio dos isótopos estáveis de carbono (13C/12C). Tese (Doutorado). Jaboticabal. Universidade Estadual Paulista - UNESP. 96 p. 2003. 